\title{
PROFESI DAN GURU
}

\author{
Muhammad Sofian Syauri \\ Email:2010111310001@mhs.ulm.ac.id \\ Program Studi Pendidikan Sejarah Fakultas Keguruan dan Ilmu Pendidikan \\ Universitas Lambung Mangkurat \\ Banjarmasin
}

\begin{abstract}
Abstrak
Guru adalah pendidik dan pengajar pada pendidikan anak usia dini jalur sekolah atau pendidikan formal, pendidikan dasar, dan pendidikan menengah. Guru-guru seperti ini harus mempunyai semacam kualifikasi formal. Dalam definisi yang lebih luas, setiap orang yang mengajarkan suatu hal yang baru dapat juga dianggap seorang guru. etik berasal dari bahasa Yunani, "ethos" yang artinya watak..Kode etika guru di Indonesia antara lain sebagai berikut : Guru berbakti membimbing peserta didik untuk membentuk manusia indonesia seutuhnya berjiwa Pancasila. Guru melaksanaakn segala kebijakan pemerintah dalam bidang pendidikan. Hakikat Organisasi Profesi Sebelum membahas mengenai organisasi sebaiknya kita mengetahui tentang apa itu organisasi dan profesi itu sendiri. organisasi yaitu susunan dan aturan dari berbagai bagian sehingga merupakan kesatuan yang teratur. Selanjutnya menurut James D. Mooney, organisasi adalah bentuk setiap perserikatan manusia untuk mencapai tujuan bersama. Chester I. Bernard, organisasi merupakan suatu sistem.

\section{Konsep Profesi dan Profesi Guru}

Profesi adalah kata serapan dari sebuah kata dalam bahasa Inggris "Profess", yang

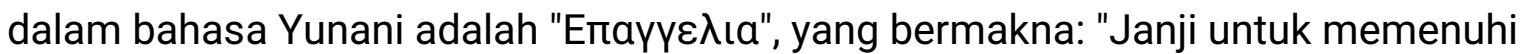
kewajiban melakukan suatu tugas khusus secara tetap/permanen".

Profesi juga sebagai pekerjaan yang membutuhkan pelatihan dan penguasaan terhadap suatu pengetahuan khusus. Profesi adalah pekerjaan, namun tidak semua pekerjaan adalah profesi. Profesi harus mempunyai beberapa hal yaitu: Keterampilan yang berdasarkan pada pengetahuan teoritis, Asosiasi Personal, dan Memiliki kode etik.

Guru adalah pendidik dan pengajar pada pendidikan anak usia dini jalur sekolah atau pendidikan formal, pendidikan dasar, dan pendidikan menengah. Guru-guru seperti ini harus mempunyai semacam kualifikasi formal. Dalam definisi yang lebih luas, setiap orang yang mengajarkan suatu hal yang baru dapat juga dianggap seorang guru.

Secara formal, guru adalah seorang pengajar di sekolah negeri ataupun swasta yang memiliki kemampuan berdasarkan latar belakang pendidikan formal minimal berstatus sarjana, dan telah memiliki ketetapan hukum yang sah sebagai guru berdasarkan
\end{abstract}


undang-undang guru dan dosen yang berlaku di Indonesia.

Guru tetap

Guru yang telah memiliki status minimal sebagai Calon Pegawai Negeri Sipil, dan telah ditugaskan di sekolah tertentu sebagai instansi induknya. Selaku guru di sekolah swasta, guru tersebut dinyatakan guru tetap jika telah memiliki kewewenangan khusus yang tetap untuk mengajar di suatu yayasan tertentu yang telah diakreditasi oleh pihak yang berwenang di pemerintahan Indonesia.

\section{Guru honorer}

Guru tidak tetap yang sering disebut Guru Honorer belum berstatus minimal sebagai Calon Pegawai Negeri Sipil, dan digaji di bawah upah minimum (UMR).Seringkali mereka digaji di bawah gaji minimum yang telah ditetapkan Undang-Undang secara resmi. Secara kasat mata, mereka sering tampak tidak jauh berbeda dengan guru tetap, bahkan mengenakan seragam Pegawai Negeri Sipil layaknya seorang guru tetap. Secara fakta, mereka berstatus Pegawai dengan pekerjaan yang sama seperti Guru Tetap namun dengan honor yang jauh berbeda. Pada umumnya, mereka menjadi tenaga sukarela untuk mengabdi dan demi diangkat menjadi Calon Pegawai Negeri Sipil melalui jalur honorer.

( https://id.m.wikipedia.org/wiki/Guru )

( https://id.m.wikipedia.org/wiki/Profesi )

\section{Guru sebagai Profesi}

Mengapa guru bisa diklasifikasikan sebagai sebuah profesi karena seorang guru memiliki keahlian khusus yang tidak dimiliki oleh pekerjaan lain maka dari itu seorang guru dapat dikatakan sebagai sebuah profesi. Dan keahlian tersebut meliputi :

(1) menguasai ilmu pendidikan, termasuk konsep, teori, dan proses,

(2) menguasai teaching learning strategies,

(3) memahami ICT dan menguasainya untuk diaplikasikan dalam proses pembelajaran, terutama untuk mendukung penerapan learning strategies yang dikembangkan oleh guru,

(4) menguasai developmental pcychology, psikologi anak, dan psikologi kognitif, 
(5) menguasi teori belajar,

(6) memahami berbagai konsep pokok sosiologi dan antropologi yang relevan dalam proses pendidikan dan pertumbuhan anak,

(7) menguasai bidang studi tertentu yang relevan dengan tugasnya sebagai guru pada jenjang persekolahan tertentu,

(8) memahami administrasi pendidikan, terutama tentang management of learning,

(9) menguasasi konsep dan prinsip pengembangan kurikulum,

(10) memahami dan menguasi pendidikan nilai,

(11) memahami proses dan dampak globalisasi serta implikasinya terhadap proses pendidikan peserta didik,

(12) memahami strategic environment yang berpengaruh terhadap proses pendidikan peserta didik,

(13) memahami peran dan pengaruh aspek sosial, kultural, dan ekonomi terhadap proses pendidikan.

( http://kompetensi.info/materi-bebas/guru-sebagai-profesi.html )

\section{Peran, Hak dan Kewajiban Guru}

Peran guru secara umum adalah sebagai tugas pendidikan meliputi mendidik, mengajar, dan melatih. Seorang guru juga berperan untuk membantu siswa dalam mengembangkan keterampilan serta pengetahuan siswa. Oleh karena itu, guru harus bisa membuat siswanya tertarik untuk mengikuti pelajaran. Hak dan Kewajiban Guru ibarat dua sisi mata uang yang harus digunakan dengan saling beriringan. Hak adalah segala sesuatu yang pantas diperoleh, sedangkan kewajiban adalah segala bentuk tindakan yang harus dilakukan. Hak biasanya diperoleh setelah melakukan serangkaian kewajiban.

Berdasarkan pasal 14 ayat 1 Undang-Undang Nomor 14 Tahun 2005 tentang Guru dan Dosen terdapat 11 hak guru:

1.emperoleh penghasilan di atas kebutuhan hidup minimum dan jaminan kesejahteraan sosial. 
2.Mendapatkan promosi dan penghargaan sesuai dengan tugas dan prestasi kerja.

3.Memperoleh perlindungan dalam melaksanakan tugas dan hak atas kekayaan intelektual.

4.Memperoleh kesempatan untuk meningkatkan kompetensi.

5.Memperoleh dan memanfaatkan sarana dan prasarana pembelajaran untuk menunjang kelancaran tugas keprofesionalan.

6.Memiliki kebebasan dalam memberikan penilaian dan ikut menentukan kelulusan, penghargaan, dan/atau sanksi kepada peserta didik sesuai dengan kaidah pendidikan, kode etik guru, dan peraturan perundang-undangan.

7.Memperoleh rasa aman dan jaminan keselamatan dalam melaksanakan tugas.

8.Memiliki kebebasan untuk berserikat dalam organisasi profesi.

9.Memiliki kesempatan untuk berperan dalam penentuan kebijakan pendidikan.

10.Memperoleh kesempatan untuk mengembangkan dan meningkatkan kualifikasi akademik dan kompetensi.

11.Memperoleh pelatihan dan pengembangan profesi dalam bidangnya.

Berdasarkan pasal 20 Undang-Undang Nomor 14 Tahun 2005 tentang Guru dan Dosen Kewajiban Guru, diantaranya:

1.Merencanakan pembelajaran, melaksanakan proses pembelajaran yang bermutu, serta menilai dan mengevaluasi hasil pembelajaran.

2.Meningkatkan dan mengembangkan kualifikasi akademik dan kompetensi secara berkelanjutan sejalan dengan perkembangan ilmu pengetahuan, teknologi, dan seni.

3.Bertindak objektif dan tidak diskriminatif atas dasar pertimbangan jenis kelamin, agama, suku, ras, dan kondisi fisik tertentu, atau latar belakang keluarga, dan status sosial ekonomi peserta didik dalam pembelajaran.

4.Menjunjung tinggi peraturan perundang-undangan, hukum, dan kode etik guru, serta nilai-nilai agama dan etika.

5.Memelihara dan memupuk persatuan dan kesatuan bangsa.

( https://www.google.com/amp/s/kependidikan.com/hak-dan-kewajiban-guru/\%3famp ) 


\section{Profesionalisme guru untuk memajukan Bangsa}

Guru menentukan masa depan bangsa kita. Di tangan gurulah masa depan bangsa ini dipertaruhkan. Sebenarnya upaya peningkatan kualitas pendidikan dari tahun ke tahun selalu menjadi program pemerintah. Kualitas pendidikan dipengaruhi oleh penyempurnaan integral dari seluruh komponen pendidikan seperti kualitas guru, penyebaran guru yang merata, kurikulum yang selalu disempurnakan setiap saat, sarana dan prasarana yang memadai, suasana pembelajaran yang kondusif, dan kualitas guru yang meningkat, serta didukung oleh kebijakan pemerintah.Ketersediaan guru yang memadai, merupakan salah satu faktor penting dalam upaya pembangunan pendidikan di Indonesia, baik secara kuantitas maupun kualitas. Dalam rangka pemenuhan ketersediaan guru yang memadai tersebut, pemerintah masih dihadapkan pada dua permasalahan pokok yang sangat mendasar. Pertama, pemenuhan kebutuhan tenaga guru yang belum sesuai dengan kebutuhan daerah, dan kedua adalah peningkatan kualitas profesional yang belum memenuhi standar minimal. Karena guru merupakan titik sentral dari peningkatan kualitas pendidikan yang bertumpu pada kualitas proses pembelajaran. Oleh sebab itu peningkatan profesionalisme guru merupakan suatu keharusan.

Profesionalisme guru dapat diwujudkan melalui pemberdayaan potensi dan prestasi guru. Seorang guru disebut sebagai guru profesional karena kemampuannya dalam mewujudkan kinerja profesi guru secara utuh. Dengan demikian sifat utama dari seorang guru profesional adalah kemampuannya dalam mewujudkan kinerja profesional yang sebaik-baiknya dalam mencapai tujuan pendidikan. Sifat-sifat ini mencakup ciri-ciri kepribadian guru dan penguasaan keterampilan teknis keguruan. Dengan kata lain seorang guru hendaknya memiliki kompetensi yang mantap. Kompetensi merupakan seperangkat pengetahuan, keterampilan, prilaku yang harus dimiliki, dihayati, dikuasai, dan diaktualisasikan oleh guru dalam melaksanakan tugas keprofesionalan.

( https://www.google.com/amp/s/www.kompasiana.com/amp/intandf/5bede4264332 2f0bec423bf2/profesionalisme-guru-dalam-mewujudkan-pendidikan-berkualitas)

\section{Kompetensi yang harus dimiliki Guru}

\section{Kompetensi Pedagogik}

Kompetensi Pedagogik Guru adalah kemampuan atau keterampilan guru yang bisa mengelola suatu proses pembelajaran atau interaksi belajar mengajar dengan peserta 
didik.

Setidaknya ada 8 aspek dalam kompetensi Pedagogik yang harus dikuasai, yaitu:

1.Karakteristik para peserta didik. Dari informasi mengenai karakteristik peserta didik, guru harus bisa menyesuaikan diri untuk membantu pembelajaran pada tiap-tiap peserta didik. Karakteristik yang perlu dilihat meliputi aspek intelektual, emosional, sosial, moral, fisik, dll.

2.Teori belajar dan prinsip pembelajaran yang mendidik. Guru harus bisa menerangkan teori pelajaran secara jelas pada peserta didik. Menggunakan pendekatan tertentu dengan menerapkan strategi, teknik atau metode yang kreatif.

3.Pengembangan kurikulum. Guru harus bisa menyusun silabus dan RPP sesuai dengan ketentuan dan kebutuhan. Mengembangkan kurikulum mengacu pada relevansi, efisiensi, efektivitas, kontinuitas, integritas, dan fleksibilitas.

4.Pembelajaran yang mendidik. Guru tidak sekedar menyampaikan materi pelajaran, namun juga melakukan pendampingan. Materi pelajaran dan sumber materi harus bisa dioptimalkan untuk mencapai tujuan tersebut.

5.Pengembangan potensi para peserta didik. Setiap peserta didik memiliki potensi yang berbeda-beda. Guru harus mampu menganalisis hal tersebut dan menerapkan metode pembelajaran yang sesuai, supaya setiap peserta didik bisa mengaktualisasikan potensinya.

6.Cara berkomunikasi. Sebagai guru harus bisa berkomunikasi dengan efektif saat menyampaikan pengajaran. Guru juga harus berkomunikasi dengan santun dan penuh empati pada peserta didik.

7.Penilaian dan evaluasi belajar. Penilaiannya meliputi hasil dan proses belajar. Dilakukan secara berkesinambungan. Evaluasi terhadap efektivitas pembelajaran juga harus bisa dilakukan.

8.Kompetensi Pedagogik bisa diperoleh melalui proses belajar masing-masing guru secara terus menerus dan tersistematis, baik sebelum menjadi guru maupun setelah menjadi guru.

\section{Kompetensi Kepribadian}

Kompetensi Kepribadian berkaitan dengan karakter personal. Ada indikator yang 
mencerminkan kepribadian positif seorang guru yaitu: supel, sabar, disiplin, jujur, rendah hati, berwibawa, santun, empati, ikhlas, berakhlak mulia, bertindak sesuai norma sosial \& hukum, dll.Kepribadian positif wajib dimiliki seorang guru karena para guru harus bisa jadi teladan bagi para siswanya. Selain itu, guru juga harus mampu mendidik para siswanya supaya memiliki attitude yang baik.

\section{Kompetensi Profesional}

Kompetensi Profesional Guru adalah kemampuan atau keterampilan yang wajib dimiliki supaya tugas-tugas keguruan bisa diselesaikan dengan baik.

Keterampilannya berkaitan dengan hal-hal yang cukup teknis, dan akan berkaitan langsung dengan kinerja guru. Adapun indikator Kompetensi Profesional Guru diantaranya adalah:

1.Menguasai materi pelajaran yang diampu, berikut struktur, konsep, dan pola pikir keilmuannya.

2.Menguasai Standar Kompetensi (SK) pelajaran, Kompetensi Dasar (KD) pelajaran, dan tujuan pembelajaran dari suatu pelajaran yang diampu.

3.Mampu mengembangkan materi pelajaran dengan kreatif sehingga bisa memberi pengetahuan dengan lebih luas dan mendalam bagi peserta didik.

4.Mampu bertindak reflektif demi mengembangkan keprofesionalan secara kontinu.

5.Mampu memanfaatkan Teknologi Informasi dan Komunikasi dalam proses pembelajaran dan juga pengembangan diri.

Dengan menguasai kemampuan dan keahlian khusus seperti yang sudah dijelaskan di atas, diharapkan fungsi dan tugas guru bisa dilaksanakan dengan baik.

Dengan demikian, guru mampu membimbing seluruh peserta didiknya untuk mencapai standar kompetensi yang sudah ditentukan dalam Standar Nasional Pendidikan.

\section{Kompetensi Sosial}

Kompetensi Sosial berkaitan dengan keterampilan komunikasi, bersikap dan berinteraksi secara umum, baik itu dengan peserta didik, sesama guru, tenaga kependidikan, orang tua siswa, hingga masyarakat secara luas.

Indikator dari Kompetensi Sosial Guru diantaranya: 
1.Mampu bersikap inklusif, objektif, dan tidak melakukan diskriminasi terkait latar belakang seseorang, baik itu berkaitan dengan kondisi fisik, status sosial, jenis kelamin, ras, latar belakang keluarga, dll.

2.Mampu berkomunikasi dengan efektif, menggunakan bahasa yang santun dan empatik.

3.Mampu berkomunikasi baik secara lisan maupun tulisan.

4.Mampu beradaptasi dan menjalankan tugas sebagai guru di berbagai lingkungan dengan bermacam-macam ciri sosial budaya masing-masing.

( https://pintek.id/blog/kompetensi-guru/ )

\section{Simpulan}

Secara umum, arti profesi adalah pekerjaan yang membutuhkan pengetahuan atau keterampilan khusus, sehingga orang yang memiliki pekerjaan tersebut harus mengikuti beberapa pelatihan agar dapat melaksanakan pekerjaannya dengan baik.Guru adalah seorang pengajar suatu ilmu. Dalam bahasa Indonesia, guru umumnya merujuk pendidik profesional dengan tugas utama mendidik, mengajar, membimbing, mengarahkan, melatih, menilai, dan mengevaluasi peserta didik.Etika profesional atau kode etik profesi adalah acuan perilaku perseorangan atau korporasi yang dianggap harus diikuti pelaku aktivitas profesional. organisasi profesi guru adalah sebuah wadah perkumpulan orang - orang yang memiliki suatu keahlian dan keterampilan mendidik yang dipersiapkan melalui proses pendidikan dan latihan yang relatif lama, serta dilakukan dalam lembaga tertentu yang dapat dipertanggungjawabkan.Peran guru secara umum adalah sebagai tugas pendidikan meliputi mendidik, mengajar, dan melatih.Seorang guru juga berperan untuk membantu siswa dalam mengembangkan keterampilan serta pengetahuan siswa. Oleh karena itu, guru harus bisa membuat siswanya tertarik untuk mengikuti pelajaran.hak guru memperoleh rasa aman dalam menjalankan tugas dan memperoleh kesempatan untuk meningkatkan kompetensi. Dan kewajiban guru yaitu mendidik dan mengajar anak murid.

\section{Referensi}

Mutiani, M., Abbas, E. W., Syaharuddin, S., \& Susanto, H. Membangun Komunitas Belajar Melalui Lesson Study Model Transcript Based Learning Analysis (TBLA) dalam Pembelajaran Sejarah. Historia: Jurnal Pendidik dan Peneliti Sejarah, 3(2), 113-122.

Mutiani, M., WARMANSYAH ABBAS, E. R. S. I. S., Syaharuddin, S., \& Susanto, H. (2019). 
Penerapan Transcript Based Lesson Analyses (TBLA) Sebagai Upaya Peningkatan Pembelajaran Sejarah Di Sma Negeri 7 Banjarmasin.

Susanto, H. (2020). Profesi Keguruan. Banjarmasin: FKIP Universitas Lambung Mangkurat.

Susanto, H., Irmawati, I., Akmal, H., \& Abbas, E. W. (2021). Media Film Dokumenter Masuknya Islam Ke Nusantara dan Pengaruhnya Terhadap Keterampilan Berpikir Kritis Siswa. HISTORIA: Jurnal Program Studi Pendidikan Sejarah, 9(1).

Syaharuddin, S., \& Susanto, H. (2019). Sejarah Pendidikan Indonesia (Era Pra Kolonialisme Nusantara sampai Reformasi). Banjarmasin: FKIP Universitas Lambung Mangkurat. 